\title{
PUBLIC THEOLOGY IN THE SOUTH AFRICAN CONTEXT
}

\author{
Etienne de Villiers \\ (University of P)retoria
}

\section{ABSTRACT}

In this article the most relevant features of South African society and the most important challenges Public Theology is faced with in this context are discussed. The most basic challenge identified is to reach agreement on the most appropriate notion of Public Theology. It is also necessary for Public Theology to help the churches and their members to overcome their uncertainty about the Christian assessment of the democratic dispensation in South Africa and the transformation policies introduced by the government. The development of an inspiring vision of the public role churches should play in South African society is identified as another important challenge. Churches would however, only be able to play an effective prophetic and constructive role in society if they embody the vision of a better society they proclaim and in this way serve as models of a better society. Public Theology is challenged to call the churches to be faithful to this vision and to prophetically criticise them when they are unfaithful to it.

Key words: Public Theology, South African Context, Black The-ology, Theology of Reconstruction.

\section{INTRODUCTION}

It has almost become an axiom of public theology that theo-logical content is co-determined by context. This does not mean that the influence a particular context exerts on public theology is always easily detectable. In fact, it is quite possi-ble that even the closest examination of a particular theological text cannot trace any link to the context in which it was written. 
Take, for example, the contribution the well-known theologi-an of the Dutch Reformed Church in South Africa, prof Jo-han Heyns, wrote for the publication Storm-kompas (Eng-lish: Compass in the storm) in 1981 in which he provided 'A theological perspective' on the church in the South African context (Heyns 1981:15-21). This contribution provoked the famous remark in the same publication by another well-known South African theologian of the Dutch Reformed Mission Church in South Africa, prof Jaap Durand: "I have a problem with the contribution of prof Heyns; with minor changes it could just as well have been written on the church in... say, Lapland" (Durand 1981:21; translated from the Afrikaans).

Prof Durand's indignation was especially inflamed by the fact that Prof Heyns wrote about the church in the South African context and its task to promote reconciliation without mentioning the injustice done to Black people that caused the conflict in South Africa or admitting the complicity and guilt of the Afrikaans churches regarding this injustice (Durand 1981:21-23).

There is, of course, a sense in which Prof Heyns's silence on the concrete situation in South Africa does confirm the co-determination of theological content by context. It was typical of leading theologians in the Afrikaans churches, who supported apartheid during the seventies and early eighties, to say very little about the political situation in South Africa. The apartheid policy was at that stage well established and supported by the majority of the members of the Afrikaans churches. There was in such a context no need to defend apartheid theologically anymore and by keeping silent as a theologian on its alleged injustices one could contribute to its continuing legitimisation (see De Villiers 1989:268-269).

What this demonstrates, is that there is no singular and also no objective way in which a particular context is reflected in theological texts. Not only does the subjective understand-ing of the context by a particular author play a decisive role in this reflection, but also the moral responsibility - or lack of it - to seriously strive to take all the relevant features of the context into account (cf. 
Tödt 1988:31-33). This is also true of my attempt in this paper to answer the question: "To what extent should the context of South African society be reflected in public theology produced by South African theologians?" It is a morally risky endeavour that may in the end be hampered by my own bias as a privileged South African white male.

I will nonetheless try to provide in this paper an unbiased sketch of relevant features of South African society, discuss the fundamental challenge to reach a common understanding on the nature and goals of South African public theology and identify some of the more specific challenges confronting public theology in the South African context.

\section{RELEVANT FEATURES OF THE SOUTH AFRICAN CONTEXT}

It is not possible to provide in the paper a comprehensive sketch of all the salient features of the South African context. I therefore would rather concentrate on some relevant features that can help to identify some of the most important challenges public theology in South Africa is confronted with.

\section{The introduction of a democratic political dispensation}

The most significant event in the recent history of South Africa was the introduction of a fully-fledged democratic political dispensation after the historic election on 27 April 1994 that brought an end to the apartheid rule. It replaced the white minority government of the National Party by a black majority ANC led government. The ANC led government wasted no time in introducing a programme of comprehensive transformation to eradicate the racial discrimination of the colonial and apartheid past, to rectify its negative effects and to promote more equality. To mention some of the most important mechanisms that were introduced to deal with the injustices of the past: The Truth and Reconciliation Commission (TRC) to deal with gross human rights violations in the past and to promote reconciliation in society, land reform legislation to counter the illegitimate alienation of land owned by 
black people, affirmative action policies to rectify racial imbalances in the composition of the workforce in the public and private sectors and the student population in tertiary educational institutions, Black Economic Empowerment initiatives to ensure a more equitable distribution of wealth and labour legislation to more effectively protect the rights of workers (cf. De Villiers 1999:8-82). The transformation policies of the government have dominated the political scene over the last eighteen years. They are strongly supported by most black people, although the government is often criticised for not implementing such policies quickly or radically enough. Many white and even some coloured people are of the opinion that the transformation policies discriminate against them.

The new constitution that was finally ratified in 1996 under-girds the transformation policies of the government, but also has a Bill of Rights that guarantees the freedom rights of individuals. From the perspective of the churches in South Africa it is important that the Bill of Right includes the right to freedom of religion, conscience and speech. It however, also constitutes the South African state as a secular one in which the separation of religion and state has to be upheld.

\section{Persisting economic insecurity and inequality}

One of the salient features of South African society during apartheid was the very high incidence of absolutely poor, mostly black, people: almost $50 \%$ of the population. During the last decade before 1994 South Africa competed with Brazil for first place on the list of countries with the highest Gini coefficient, which indicates the degree of economic inequality. In the case of South Africa the Gini coefficient during this period consistently remained above 0.600 . The hopes of poor black people that their economic situation would drastically improve after the ANC led government took over political power in 1994 were high. Nineteen years into the new democratic political dispensation one unfortunately has to conclude that to a large extent these hopes have been disappointed. What cannot be denied is that quite a number 
of black people have moved into the middle class, mainly as a result of the employment policies of the government. Also as a result of Black Economic Empowerment initiatives, a small percentage of black people have in the meantime joined the ranks of the really rich in South Africa. What is also true is that the government has extended the allocation of social grants to a higher percentage of elderly poor people and, for the first time, to mothers with children. The provision by the government of houses for people in townships has been accelerated and the percentage of people who have access to clean running water has increased considerably.

Such measures have helped to cushion the negative effects of absolute poverty for many, but have for the most part, not succeeded in overcoming the high incidence of poverty which still exists in South Africa. In 2008, 54\% of South Africans still lived on less than R515 ( $\pm € 50$ ) per capita per month, and $70 \%$ on less than R949 ( $\pm € 90$ ) per capita per month. Economic inequality has also continued to deepen and as discussed by respondents to the SA Reconciliation Barometer Expert Survey, increasingly presents as among the most significant social fault lines in the country at pre-sent. Based on the findings of the 2005/06 Income and Ex-penditure Survey (IES), Statistics South Africa reports that the poorest $40 \%$ of the population accounts for less than $7 \%$ of total household income nationwide, and the poorest $20 \%$, less than $1.5 \%$. The Presidency's 'Development Indicators' reports an increasing Gini coefficient of 0.640 in 1995 and 0.679 in 2008, based on IES data (LefkoEverett e.a 2010:15).

The lack of improvement in the economic security of a large portion of the South African population during the last nineteen years can be ascribed to both global and national factors. Economic growth on account of the dominant neo-liberal capitalist model of economic globalisation during this period has in most countries not been accompanied by a higher employment rate and has rather led to an increase in economic inequality. Efforts of the South African govern-ment to reap the benefits of economic globalisation by adapting its economic policy (called the GEAR policy) have not had the 
desired result for poor people. The global eco-nomic recession since 2008 has also impacted negatively on the economic position of the poor in South Africa. Steve de Gruchy identifies two national factors. The first is that the outcome of the Constitutional Assembly negotiations that led to the transfer of political power in 1994 was that the bulk of the land in South Africa remained in the private possession of white people. The land reform efforts of the government to increase the access of poor black people to land since 1994 have also been rather ineffective.

The second is the devastating effect that the very high rate of HIV/AIDS infection has had on the economic security of especially poor people. At the end of 2002 an estimated 5.3 million people - mostly poor black people - out of a population of 42 million, were infected by HIV/AIDS. As a result of HIV/AIDS the South African Bureau for Economic Research predicted in 2001 that growth would decrease by half a percent for each year through to 2015 (De Gruchy 2004:231-234). To this a number of other factors can be added. The most important is probably the fact that in spite of relatively high government expenditure on education and the implementation of many reform measures, black youth in poor areas still get poor and often inappropriate education at primary and secondary levels.

This is of pivotal importance because proper education has to be regarded as one of the most important 'substantive freedoms' - to use a term of Amartya Sen - that is needed to improve a person's economic position (Sen 1999:18, 24, 193-199). The lack of proper education accounts for the fact that South Africa, in spite of its high official unemployment rate of $25.3 \%$, today has according to some estimates $-800,000$ vacancies in skilled jobs.

\section{A high crime rate expressing a deeper moral crisis}

South Africa has unfortunately gained the reputation, both nationally and internationally, of an unsafe society with a high crime rate. This reputation is, on the one hand, fueled by the extensive and often excessive media coverage 
of especially violent crime in South Africa. One of the results is that South Africans feel increasingly unsafe after dark in their own neighbourhood despite declining crime levels. Surveys have shown that the percentage of South Africans feeling very unsafe increased by $148 \%$ between 1998 and 2007 (Burger 2010). On the other hand, it cannot be con-cluded that this reputation is only based on false percep-tions. Although the number of recorded incidences of the twenty most serious crimes has gone down from \pm 2700000 in 2002/2003 to \pm 2500000 in 2008/2009 the crime rate is still high in comparison with international standards. To mention only the murder rate: Although the murder rate has gone down from 78.9 per 100000 of the population in 2002/2003 to 37.6 in 2008/2009 it is still exceedingly high in comparison with the international average of 7.6. While it may be true that the incidence of some forms of violent crime (murder, common assault, aggravated robbery) has been in decline over the last few years, the incidence of other forms of crime like business crime, house robberies and carhijackings has been on the increase (Burger 2010).

Comprehensive research on violent crime in South Africa carried out by the Centre for Reconciliation and Violence at the University of the Witwatersrand identified the following causes for the high incidence of violent crime in South Africa (Bruce 2010):

(i) Structural factors. The strong inequality in South Africa feeds into violence on account of the experience of 'relative deprivation', but even more so on account of the fact that it reinforces feelings of inadequacy (low self worth). Especially in the South African context inequality '(a)ccentuates already strong feelings of low self-esteem and inadequacy about status, entrenched by decades of apartheid racism and the 'historical trauma' of colonialism' (Bruce 2010).

(ii) Child rearing and youth socialisation. Some of the following risk factors research has identified on the 'family' level as strongly correlated with delinquency present themselves strongly in the South African context: poor parental supervision, parental conflict, an 
antisocial parent, a young mother, large family size, low family income, and coming from a broken family.

(iii) The role of the criminal justice system. For example, the overcrowding of South African prisons and the lack of rehabilitation programmes, have the result that prisons do not consistently contribute to improvements in behaviour, and may be seen to reinforce criminality.

(iv) The culture of violence. South Africa was affected by high levels of political violence in the 1970s and particularly the 1980s/90s. This political violence made violence socially acceptable feeding into high levels of criminal violence.

These contributing factors reveal that the high incidence of crime, especially violent crime, points to a deeper moral crisis in South Africa: the persistence of morally unacceptable inequality and the serious lack of strong moral formation as a result of the disruption of family life, and - one can add - the dismantling of traditional morality, especially traditional morality guiding sexual behaviour (cf. De Gruchy 2004:236-241).

\section{The lack of reconciliation and social cohesion}

Apartheid was based on the fear of especially the Afrikaner people in the past that peaceful co-existence would be im-possible in an integrated South African society with a majority government. Peaceful co-existence, the majority of them believed, would only be possible if the different ethnic groups had political independence and members of ethnic groups could socialise primarily with other members of their own ethnic group. The irony is that apartheid, as a result of the discriminatory measures that were introduced to enforce its aims, soon led to increased strife and enmity between ethnic groups in South Africa. Today relations between different ethnic groups are still bedevilled by the strong race consciousness and racial enmity apartheid produced. This does not mean that there has not been any improvement in the relations between population groups in South Africa. The 
annual SA Reconciliation Barometer Expert Survey of the Institute for Reconciliation and Justice at the University of Cape Town indicates that there has been a steady improvement in some respects, but that little improvement can be shown in other respects. For example, in 2010, just over $60 \%$ of South Africans agreed that they are trying to forgive those who hurt them during apartheid, and in fact only $5 \%$ disagreed or strongly disagreed with this statement. Similarly, only $5 \%$ disagreed that they want to forget about the past and move on with their lives, compared to $72 \%$ agreement. However, while these are relatively positive findings, almost two-fifths of South Africans (39\%) still believe it is fair that those who discriminated against others under apartheid should be discriminated against: a percentage that has remained fairly consistent over ten rounds of the survey. Also in 2010, $62 \%$ of South Africans agree that they find the customs and ways of others difficult to understand, and a longitudinal evaluation shows a marginal increase in this percentage over time. A further $35 \%$ of South Africans view people of other race groups as untrustworthy in 2010, and this has remained fairly consistent over survey rounds (Lefko-Everett e.a. 2010:7).

South African society, immediately after the transition to the new political dispensation and during the presidency of Mr Nelson Mandela, went through a 'honeymoon' period in which it seemed that the miracle of the peaceful transition also included the miracle of overcoming all racism and racial tension. Unfortunately, since the inauguration of Mr Mbeki as president, racial tensions - not only between whites and blacks, but also between Africans and coloureds - have resurfaced and open racist remarks and incidents, involving both whites and blacks, have been on the increase. What has also become very clear is that social cohesion in South Africa is not only threatened by racial tension, but increasingly so by class tension. The increase of service delivery protests in townships is a clear indication that poor black people are losing their patience with the government's ineffectiveness in overcoming the huge divide between rich and poor in South Africa. The increasing number of xenophobic attacks on refugees and immigrants from other African countries over the last few years is another indication of the angry mood of the poor. 


\section{THE NATURE AND GOALS OF PUBLIC THEOLOGY IN THE SOUTH AFRICAN CONTEXT}

The South African context poses a number of serious chal-lenges to those South Africans who are actively involved in Public Theology. The most fundamental of these challenges is to reach a common understanding on the nature and goals of Public Theology in South Africa. That the notion of Public Theology is still a contested one in South Africa, has become clear to me when the Centre for Public Theology of the University of Pretoria invited Prof William Storrar, the first chairperson of the Global Network for Public Theology, to participate in a symposium on 'Responsible South African Public Theology in a Global Era' in August 2008. In the public lectures Prof Storrar presented he developed a concept of Public Theology that departs from Jürgen Habermas's notion of the public sphere (cf. Habermas 1989). He was of the opinion:

A truly public theology is to be found operating in the public sphere, the place of public communication and argumentation. If, with Habermas, we agree that the public sphere is 'a domain of our social life in which public opinion can be formed', where any and all citizens can gather freely and without coercion to consider matters of general interest, then a public theology must be a discourse that circulates in this public sphere and both informs and is informed by public opinion on public matters. (Storrar 2011:27-28)

This notion of Public Theology is clearly normative. Certain requirements first have to be met, before one can be said to engage in public theology. Storrar therefore concluded that 'where such a public sphere does not exist or operate, we cannot speak of a public theology... although we could speak of a liberation theology, for example, which contested the exclusion of the poor or other parties from history' (Storrar 2011:28). As such a public sphere only exists in a democracy the conclusion is inevitable that public theology can only function properly in a democracy.

At the symposium this normative notion of Public Theology met with 
resistance from certain South African theologians such as, Tinyiko Maluleke who in his response to Storrar's first public lecture provided criticism from a Black Theology perspective (Maluleke 2011:79-89). Maluleke's criticism of Storrar's notion of Public Theology reminds one of the criti-cism he and other Black theologians expressed of Charles Villa-Vicencio's notion of a 'Theology of Reconstruction' in the early nineties (Villa-Vicencio 1992). Villa-Vicencio ex-pressed the opinion that the transition to a democratic dis-pensation marked a completely new situation that demand-ed a new theological paradigm. There is, in his opinion, in the new democracy the need to take leave of the paradigm of liberation in theology, characterised by the 'No!' of resist-ing an oppressive regime and to shift to the new paradigm of reconstruction, characterised by the 'Yes!' of affirming the democratic accomplishment of political liberation and engaging with the challenge to create an all-inclusive society (Villa-Vicencio 1992:7-8)

The Black theological criticism of both Villa-Vicencio's The-ology of Reconstruction and the normative conception of Public Theology espoused by Storrar can be summarised as follows:

(i) The main problem Black theologians have with both is the suggestion that the paradigm of liberation, as well as the theological contribution of Liberation Theology and Black Theology can be left behind in the new democratic situation in South Africa. As the full liberation of previously disadvantaged black people is not yet completed, especially not their economic liberation, there is no reason to leave the paradigm of liberation behind in the democratic South Africa. Maluleke, in his response to Storrar's view of Public Theology, alluded to this need for the continuance of the liberation effort when he asked: 'This public sphere where strangers meet with civility - where can we find it? In Paris under the gaze of the Eiffel Tower? In the middle of Kotze street in Hillbrow Johannesburg? At that street in Ramaphosa Squatter camp outside Johannesburg where Ernesto was recently burnt alive for the fault of being Mozambican?' (Maluleke 2011:85). 
(ii) By contrasting the Theology of Reconstruction and Public Theology with Liberation Theology, Villa-Vicencio and Storrar suggest that Liberation Theology cannot be reconstructive or constructive and is not public in nature. Such contrasting is, however, misleading. There is no reason to deny Liberation Theology the ability to also be reconstructive or constructive in situations that require such an approach. And to deny liberation theology the status of Public Theology is to fail to appreciate the thoroughly 'public' nature it has always had.

(iii) Both the Theology of Reconstruction and the normative notion of Public Theology have the pretence that they are universal in nature and transcend all theological, cultural and class differences. In his response Maluleke had the following to say: 'Nothing that I have read on public theology reassures me that this is not yet another phase of Christian theology's attempts to pattern and framework a world that is not only diverse but grossly unequal. Elements of public theology exhibit the same old search for universal theology - in the name of a universal public, universal stranger and common universal issues' (Maluleke 2011:84; see also on the pretence of universalism in Reconstruction Theologies Vellem 2007:157).

The criticism of Storrar's normative notion of Public Theolo-gy by another South African theologian present at the sym-posium, James Cochrane, overlaps considerably with the black theological criticism of Tinyiko Maluleke. He was also of the opinion that there is something incongruent in the argument that theologies that directly represent public anger, including Black Theology, Kairos Theology and many forms of Liberation Theology, cannot be called Public Theology, despite the fact that they are deliberately public in intention, just because they are "oppositional' or protest theologies, not yet oriented towards the conditions of publicity, which depend upon a genuinely open and democratic sphere of publicity (Cochrane 2011:47).

In Cochrane's opinion Storrar espouses a too narrow view of what constitutes 


\section{Public Theology. One reason for such a judgment is:}

If... a public theology is defined as such only where the conditions of participation are, to a greater or lesser extent, already met, then vast regions of society in the great majority of existing nations cannot be the context for public theology. Equally seriously, the global commons cannot be such a context either, outside of a very limited number of forums within which certain people - one might even say certain classes of people - are able to act. (Cochrane 2011:55).

Cochrane is of the opinion that the split between public an-ger and public spirit that lies within Storrar's distinction be-tween oppositional and public theologies is problematic. It is his view that both these moments necessarily belong to-gether, and that both are forms of Public Theology. The challenge is to find a framework for seeing the task of public theologies in such a way that the critical, excluded moment of public anger is not opposed to the reconstructive, included moment of civic spirit (Cochrane 2011:62).

I agree with the criticism that Storrar's notion of Public The-ology is just too narrow to serve as point of departure in the South African context. Not only does his notion of Public Theology deny the important public role of Liberation Theol-ogy in the recent history of South Africa, but it also does not acknowledge the need for ongoing liberation in this society. The discussion of some of the relevant features of South African society in the preceding paragraph has clearly demonstrated that a large part of the population needs to be liberated from absolute poverty and unjust social structures that maintain a high economic inequality. I therefore also agree with Cochrane that a more inclusive and comprehen-sive notion of Public Theology is needed in South Africa that would include the ongoing liberation of South African society. The prophetic witness that was an outstanding feature of Liberation Theology should, as a result, also be part and parcel of the Public Theology that is practiced in South Africa. This does, however, not mean that the fact that we now have a democratic dispensation in South Africa is of no 
relevance. There are also other goals that should be promoted by Public Theology besides liberation, like the utilisation of the space provided in the new democracy for churches and theology to in their own way contribute to the reconstruction of society. And there are also other modes of public discourse that should be utilised besides the prophetic mode, such as the ethical and policy modes James Gustafson also regards as legitimate modes of public discourse (cf. Gustafson 1988).

As Dirkie Smit has pointed out there are also other notions of Public Theology, besides the one that departs from Ha-bermas's normative concept of the public, that are also more inclusive (Smit 2007). A second notion relates to a vaguer, but also more common, understanding of 'public' as life in general, life in the world, or social life. Public Theology that departs from this understanding usually focuses on issues regarding the place, social form and role of the church in this broad public. A third notion relates to an even vaguer understanding of 'public'. Here 'public' refers to the different audiences or spheres theology can engage. In David Tracy's typology the three publics of theology are: society, academy and church. Public Theology can as a result deal with the relation of theology to society, the academy or the church (Tracy 1991).

In my opinion we should give preference in the South Afri-can context to the second version of Public Theology Dirkie Smit refers to. Public Theology, in my opinion, ought to be understood in the South African context as theological re-flection on the place, social form and role of the church in broader society. This would be an acknowledgement of the indispensable and influential public role churches played in South African society in the past, the great need that still exists in society for them to play such a role and the great potential they still have to make a constructive contribution to society. Both the concept of 'church' and the concept of 'broader society' should, however, be understood inclusive-ly. 'Church' should refer not only to church denominations, but also to theological institutions, ecumenical organisations, local congregations, voluntary Christian societies and indi- 
vidual Christians. 'Broader society' should include global society, the African continent, South African society and local communities, but also the differentiated social spheres of politics, the economy, religion, culture, art, science and technology. Public Theology in South Africa should therefore include research on such diverse topics as: the place and role of theology in state universities, the prophetic task of ecumenical organisations regarding economic globalisation, the public role of church denominations in the new political dispensation in South Africa and the responsibility of individual Christians to fight corruption in the civil service and in business companies.

\section{CHALLENGES THE SOUTH AFRICAN CONTEXT POSES TO PUBLIC THEOLOGY}

What are the more specific challenges the South African context poses to the practitioners of Public Theology in South Africa? In close connection to what has already been I will in the last part of my paper briefly discuss some of the challenges, which are in my opinion the most important:

1. To develop a well-founded theological view on the democratic dispensation in South Africa.

Gerrit de Kruijf, in a discussion of the attitudes of Western-European theologians and churches over against democra-cy in the first seven decades of the 20th century, makes the remark that to a large extent the theocratic views that were part of their theological tradition prevented them from embracing democracy with enthusiasm. They pragmatically made use of the freedom democracy provided to them to further their own Christian views and causes, but found it difficult to theologically endorse democracy (De Kruijf 1994:151-165). This, to some extent, is also true of many theologians and churches in South Africa today. They ac-cept the new democratic dispensation, because it is the po-litically correct thing to do, but they have their theological reservations about certain aspects of it. It is above all the separation of church and state that does not sit well with them, because they were used to base their public theologi-cal discourse on theocratic 
confessional beliefs (Reformed theologians and churches) or are still convinced that such discourse should be directly based on the Bible (pastors and members of the growing Pentecostal churches). Many of them are also uncomfortable about the close association of human rights with individualism and liberalism.

In my opinion it has become time for South African theologians and churches to make a thorough theological assessment of the specific democratic dispensation we have in our society. Special attention should be given to the following questions: Should the 'soft' separation of religion and the state that the South African constitution promulgates be theologically denounced, or should it rather be theologically regarded as the optimal way to regulate the relationship between religious denominations and the state? Is the Bill of Rights in the constitution to be theologically criticised as an expression of one-sided individualism and liberalism or should the creative tension in which freedom and social rights are juxtaposed rather be theologically commended? And: should the transformation measures that are endorsed by the constitution, such as affirmative action and land reform, be regarded as discriminatory over against white people, or rather as inevitable measures that have to be maintained for a limited period to bring about a more just society? Only on the basis of such a thorough theological assessment would theologians and churches overcome their ambivalent and inconsistent views and attitudes over against the new democratic dispensation, and would they be able to provide guidance to church members on human rights issues and the transformation policies of the government.

2. To develop an inspiring theological vision of the pub-lic role of theology and the church in the democratic South Africa.

Until the introduction of the new democratic dispensation most of the mainline churches in South Africa and theologi-ans associated with them took it for granted that it is the duty of the church to work for the transformation of society into one in which the lordship of Christ is recognised 
and the law of God obeyed in all spheres of life. This transformation approach to the public role of theology and the church, based on theocratic assumptions, has since the introduction of the new democratic dispensation undergone a serious legitimacy crisis. Not only have the credibility structures that undergirded this approach fallen away - a constitution and government supporting the promotion of Christian values in society and a liberation movement in which Liberation Theology and church leaders played an important motivational role - but has the separation of religion and state promulgated by the constitution of the new democratic dispensation also seemingly made the transformation approach obsolete.

In my opinion there is no reason to completely abolish the transformation approach and opt for the inward-directed spirituality and theology that has become influential in many South African churches since 1994. To do so would be to turn our back on the strong Reformed and Liberation Theol-ogy traditions in South Africa. What is needed is a reinter-pretation of the transformation approach to turn the exclu-sive nature it had in the previous political dispensation into a more inclusive one. Not the Christianisation of society should be the goal of the transformation of society and the public role of theology and the churches, but rather the hu-manisation, or even more comprehensively, the protection and flourishing of life on earth (cf De Villiers 2005: ). Such an approach would still involve the prophetic witness of theology and the churches against policies and actions - whether of the government or other institutions - which go against these goals, as well as their constructive engage-ment in projects promoting these goals.

What exactly is the constitutional and political scope in democratic South Africa for theology and the churches to do just that? On the one hand it is true that this scope is in some respects more restricted than in the previous political dispensation. As a result of the separation of religion and state required by the present constitution no religious denomination is allowed to have a privileged relationship with the government, and the government is not allowed to base its legislation on the specific beliefs of one particular 
religion. On the other hand the same constitution that separates religion and state also recognises human rights such as freedom of religion, freedom of conscience and freedom of speech. All church denominations and their members have the right to freely express their opinion in the public sphere by means of their own communication channels and the mass media. Of special importance is that the separation of religion and state required by the constitution is what one can describe as a "soft" one. Section 15 of the Bill of Right in the constitution does not imply neutrality over against religions but impartiality. It makes allowance for religious observances in state institutions and some cooperation between the government and religious denominations on an equitable basis (cf De Villiers 2010:203-205).

Some important conclusions can be drawn from this regarding the constitutional scope theology and the church has to play a public role:

(i) There are no legal restrictions on them, and therefore also no excuse for them, to exercise their prophetic calling to publicly criticise morally unacceptable government policies and practices in society (cf. Coertzen 2008: 345-367). Our review of some of the relevant features of South African society has shown that there is a great need for such prophetic witness. The persisting vast economic inequality, which manifests itself, amongst others, in a high percentage of people who are absolutely poor, is from a moral perspective probably the most deplorable feature of South African society Theology and the churches cannot but on an ongoing basis prophetically condemn this inequality, expose the structural factors that contribute to it, criticise the selfish attitudes and actions of rich companies and individuals that solidify it and protest against the inadequate and ineffective policies and service delivery of the government that has achieved very little over the past nineteen years to overcome it. Prophetic witness is also needed against racist attitudes, remarks and actions and xenophobic intolerance over against African refugees that undermine social cohesion. The sloth of teachers and inappropriate government 
educational policies that contribute to poor education, the overcrowded conditions in prisons, the greed and strong culture of entitlement that contributes to the high rate of crime and corruption and the promiscuity and lack of sexual self-discipline that lead to the high rate of abortions, teenage pregnancies, and HIV/AIDS should also be the focus of prophetic witness.

Should this prophetic witness of theology and the churches always be presented in explicitly Christian language? In my opinion, it would be wise to take Michael Walzer's depiction of authentic prophecy as 'connected social criticism' as point of departure. Walzer is of the opinion that authentic prophetic witness is based on values that are shared by the addressor and the addressee(s) (Walzer 1987:37-39, 2002:xii). The implication is that the prophetic witness of theology and the churches in South Africa, could and should be based on shared Christian values and makes use of explicit Christian language when it is addressed to people who are Christian, recognise Christian values and understand Christian language. Of course, in South Africa, a high percentage of the population is still adherents of the Christian faith, understands Christian language and shares Christian values. This means that theology and the churches can get far with prophetic witness in a Christian vein, whether that witness is delivered in the church or in the public media. However, what should be taken into account is that there is a considerable percentage of the population who are adherents of other religions or are non-religious. If theology and the churches also want to convince them or have as purpose the persuasion of the government or business companies to adjust their policies, explicit Christian language should rather be avoided and arguments be based on values that are shared by most South Africans or are imbedded in the constitution.

(ii) Also with regard to constructive engagement with the serious social problems in South Africa theology the churches have a wide scope. Indeed, one can say that there is a strong need for such constructive 
engagement. The South African government just does not have the capacity to handle all the dimensions of these social problems in an effective way. Besides, it is today globally acknowledged that the contribution of NGO's - and that includes religious denominations - in combating social problems is indispensable (cf. Hubig 1995: 106-107; Heidbrink 2003: 187-256). Combating poverty and injustice, caring for the sick, reconciling people who are estranged from one another, contributing to moral formation and building healthy marriages and family relationships have always been part of the core activities of churches. They have built up a certain expertise in handling these matters and have developed - each in its own way - an infrastructure of services. The South African churches are in this respect no exception.

On account of the understanding of the separation of reli-gion and the state in the South African constitution as a 'soft' one there is also scope for some co-operation between the government and the churches in combating these social problems. The government decided to continue funding religious welfare service providers, but only if they meet the requirements set out by the Department of Social Development in its "Policy on financial awards to service providers" of 2007. Mainly as a result of the fact that the Department spends an average of $90 \%$ of its budget on social grants, and only $10 \%$ of the budget is left for a wide range of welfare services, government funding for social welfare services has not substantially increased in real terms (Department of Social Development 2007). In addition, government funding for welfare services now has to be spread over a far greater number of service providers, with the result that church social welfare services now have to accept that a smaller percentage of their expenses is funded by the government than previously.

The churches now also have to accept that they have no direct access to the government to negotiate the terms of government support or to make input regarding government policies on social development. 
The government has insti-tuted an inter-religious negotiation forum, the National Reli-gious Association for Social Development, for interaction with the Department of Social Development. This forum can, however, only negotiate effectively with the government on the basis of strong consensus on proposals regarding social development policy among its members. Again, churches are faced with the challenge to present their own proposals in a language that can be understood and with arguments that can be accepted by nonChristians.

In the case of education and religious education there is unfortunately very little cooperation between the churches and the government. The churches and the government have not seen eye to eye on their interpretation of the implications of Section 15 of the Bill of Rights for church involvement in education and religious education. Churches and Christian theologians, in the long public debate leading to the promulgation of the government "Policy on religion and education" in 2003, argued that Section 15 allowed for government funding of church schools and single-faith religious education in public schools on the basis of fairness. In its policy the government, however, takes another stance. The policy acknowledges the right of citizens to establish independent schools, including religious schools, but for the most part at their own expense. It also does not make allowance for a single-faith or even multiple single-faith approach to religious education, but rather introduces a multi-tradition Religion Education approach that does not promote any particular religion, but exposes pupils in an objective manner to the belief systems and practices of the different religions in South Africa. This does not exclude the possibility of occasionally utilising guest facilitators from various religions. Representatives of religious organisations are also invited to voluntarily contribute to the development and distribution of suitable materials for use in Religion Education (Department of Education 2003). 


\section{To challenge churches to be models of a better society}

The view on Public Theology developed in this contribution differs considerably from the view of Stanley Hauerwas that theology and the churches should not in liberal societies take part in the public debate on social justice and try to in-fluence government policies on social justice issues. In Truthfulness and tragedy he succinctly formulates his view: "The church... must act as a paradigmatic community in the hope of providing some indication of what the world can be, but is not... The church does not have, but rather is a social ethic" (Hauerwas 1977: 142-143). I differ from Hauerwas in that I do believe that theology and the churches, even in societies with a liberal democratic constitution, have a prophetic and constructive role to play regarding societal issues. I agree, however, with him on the importance of the faithfulness of churches to the moral values they proclaim. The prophetic witness of churches on societal issues has no legitimacy in contemporary societies if they do not practice what they preach. In South Africa the prophetic witness of churches is undermined in more than one way by church structures and practices that are not in tandem with this witness. There are churches in South Africa that preach forgiveness and reconciliation as moral obligations, but have not after all these years succeeded in overcoming racism and racial tension in their midst, or even worse, still remain divided in racially separate church structures as in the time of apartheid. There are still churches in South Africa that every Sunday proclaim the biblical message of a just God and the command for neighbourly love, but at the same time maintain a strict patriarchal order and do not allow women in leadership positions. Such gender discrimination flies in the face of the constitutional requirement of gender equality and does little to improve the legitimacy of churches in the broader South African society. Public Theology in South Africa should in the first instance direct its prophetic witness against such morally unacceptable structures and practices of churches and challenge them to be models of a morally better society. 


\section{CONCLUSION}

In this contribution I have discussed some of the most rele-vant features of South African society and in the light of these features also identified and discussed some of the most important challenges Public Theology is faced with in the South African context. The most basic challenge is for practitioners of Public Theology to reach agreement on the most appropriate notion of Public Theology. It is also neces-sary for Public Theology to help the churches and their members to overcome their uncertainty about the Christian assessment of the democratic dispensation in South Africa and the transformation policies introduced by the govern-ment. The development of an inspiring vision of the public role churches should play in South African society has been identified as another important challenge. Churches would, however, only be able to play an effective prophetic and constructive role in society if they embody the vision of a better society they proclaim and in this way serve as models of a better society. Public Theology is challenged to call the churches to be faithful to this vision and to prophetically criticise them when they are unfaithful to it

\section{BIBLIOGRAPHY}

Bruce, D 2010. The nature and causes of violent crime in South Africa. Unpublished paper read at the conference of the Centre for Public Theology, University of Pretoria, on 'Violence in the democratic South Africa: A challenge to theology and the churches', 10-12 August 2010.

Burger, J 2010. SA's (violent) crime profile. Unpublished paper read at the conference of the Centre for Public Theology, University of Pretoria, on 'Violence in the democratic South Africa: A challenge to theology and the churches', 10-12 August 2010.

Cochrane, JR 2011. Against the grain: Responsible public theology in a global era, International Journal of Public Theology 5:1, 44-62.

Coertzen, P 2008. Freedom of religion: then and now 1652-2008. Verbum et Ecclesia 29(2), 345-367. 
De Kruijf, GC 1994. Waakzaam en nuchter: Over christelijke ethiek in een democratie (Vigilant and level- headed: On Christian ethics in a democracy), Baarn: Ten Have.

De Gruchy, S 2004. From church struggle to church struggles, in JW de Gruchy, with $S$ de Gruchy. The church struggle in South Africa. 25th anniversary edition. London: SCM Press, 223-260.

Department of Education 2003. National policy on religion and education.

Department of Social Development 2007. Policy on financial awards to service providers.

De Villiers, DE 1989. Kuitert en die politisering van die kerk in Suid-Afrika (Kuitert and the politicising of the church in South Africa), in KU Gäbler, G Manenschijn e. a. (eds), Geloof dat te denken geeft. Opstellen aangeboden aan prof dr HM Kuitert (Faith that provokes thought. Essays offered to prof dr HM Kuitert). Baarn: Ten Have, 258-274.

De Villiers, DE 1999. Challenges to Christian ethics in the present South African society, Scriptura 69, 75-92.

De Villiers, DE 2005. The vocation of the Reformed ethicist in the present South African society. Scriptura 89, 521-535.

De Villiers, DE 2010. The public role of churches in present South Africa, in JD Gort, H Jansen \& W Stoker (eds). Crossroad discourses between Christianity and culture. Amsterdam/New York: Rodopi, 197-214.

Gustafson, J 1988. Varieties of moral discourse: Prophetic, narra-tive, ethical and policy, Grand Rapids: Calvin College and Seminary Library.

Habermas, J 1989 (1962). The structural transformation of the public sphere: An inquiry into a category of bourgeois society (trans. T Burger and $F$ Lawrence). Cambridge: Polity Press.

Hauerwas, S 1977. Truthfulness and tragedy: Further investigations in Christian ethics. Notre Dame: University Press.

Heyns, JA 1981. ' $n$ Teologiese perspectief (A theological perspective), with commentary by J Durand, in NJ Smith, FE O'Brien Geldenhuys \& P Meiring (eds), Storm-kompas. Opstelle op soek na 'n suiwer koers in die SuidAfrikaanse konteks van die jare tagtig (Compass in the storm. Essays in search of the right course in the South African context of the eighties). Cape Town: 
Tafelberg, 15-23.

Heidbrink, L 2003. Kritik der Verantwortung: Zu den Grenzen verantwortlichen Handelns in komplexen Kontexten. Weilerswist: Velbrück Wissenschaft.

Hubig, C 1995. Verantwortung und Hochtechnologie. In: K. Bayertz (Hrsg.). Verantwortung: Prinzip oder Problem? Darmstadt: Wissenschaftliche Buchgesellschaft, 98-139.

Lefko-Everett, K, Lekalake, R, Penfold, E \& Rais, S 2010. 2010 Reconciliation barometer survey report. Cape Town: Institute for Justice and Reconciliation. Maluleke, TS 1994. The proposal for a theology of reconstruction: A critical appraisal, Missionalia 2/3, 254-258.

Maluleke, TS 2011. The elusive public of public theology: A re-sponse to William Storrar, International Journal of Public Theology 5:1, 79-89.

Sen, A 1999. Development as freedom. New York: Alfred A Knopf.

Smit, DJ 2007. Notions of the public - and doing theology: Tentative thesis for discussion, International Journal of Public Theology 1:3/4, 431-454.

Storrar, W 2011. The naming of parts: Doing public theology in a global era, International Journal of Public Theology 5:1, 23-43.

Tracy, D 1991. The analogical imagination: Christian theology and the culture of pluralism. New York: Crossroad.

Vellem, V 2007. The symbol of liberation in South African public life: A Black theological perspective PhD thesis. Pretoria: University of Pretoria.

Villa-Vicencio, C 1992. The theology of reconstruction. Cambridge: University Press.

Walzer, M 1987. Interpretation and social criticism. Cambridge: Harvard University Press.

Walzer, M 2002. The company of critics: Social criticism and political commitment in the twentieth century. New York: Basic Books. 